\title{
MELATIH SISWA BERPIKIR HISTORIS DENGAN MODEL PEMBELAJARAN INQUIRY TRAINING (LATIHAN PENELITIAN)
}

\author{
Maulana Muhammad \\ Program Studi Pendidikan Sejarah FKIP Universitas Lambung Mangkurat \\ Banjarmasin
}

Email: 1710111310006@mhs.ulm.ac.id

\begin{abstract}
Abstrak : Pembelajaran sejarah tidak terkecuali dari pembelajaran bidang ilmu lain memerlukan berbagai inovasi. Pengembangan ini dapat dilakukan dengan aplikasi model pembelajaran yang sesuai dengan sasaran pembelajaran sejarah. Salah satu kemampuan siswa dalam belajar sejarah adalah siswa memiliki kemampuan berpikir historis. Sebagai alternatif model pembelajaran yang dapat digunakan dalam melatih kemampuan berpikir historis adalah model latihan penelitian.

Model pembelajaran Latihan Penelitian (inquiry training model) merupakan salah satu model pembelajaran yang dapat memunculkan konteks penelitian yang sangat mendukung untuk berkembangnya keterampilan-keterampilan kognitif. Model Latihan Penelitian merupakan model pembelajaran yang sangat kuat mengedepankan konteks permasalahan, dengan demikian model ini juga sangat sesuai untuk mengembangkan keterampilan kognitif tingkat tinggi. Pembelajaran dengan pendekatan saintifik dalam Model Latihan Penelitian juga sangat mengedepankan kemandirian peserta didik dari mulai merumuskan masalah hingga mengevaluasi proses-proses / prosedur-prosedur penelitian yang telah dilaksanakan. Namun model ini juga masih memberikan keleluasaan bagi guru / dosen untuk mengarahkan proses penelitian yang akan berlangsung dengan mengedepankan fenomena-fenomena yang telah dipilih dan dipertimbangkan oleh guru / dosen yang bersangkutan.
\end{abstract}

Kata Kunci : Berpikir historis, model pembelajaran latihan penelitian.

\section{PENDAHULUAN}

Istilah model dapat diartikan sebagai kerangka konseptual yang digunakan sebagai pedoman dalam melaksanakan suatu kegiatan (Winaputra, 2005:3). Model dapat juga dimaksudkan bahwa benda tiruan dari benda yang sesungguhnya. Misalnya, mobil mainan, rumah mainan atau senjata mainan.

Model kaitannya dengan pembelajaran yang biasa disebut dengan model pembelajaran diartikan sebagai kerangka konseptual yang melukiskan prosedur yang sistematis dalam mengorganisasikan pengalaman belajar untuk mencapai tujuan belajar tertentu, dan berfungsi sebagai pedoman bagi para perancang pembelajar dan para pengajar dalam merencanakan dan melaksanakan aktivitas pembelajaran (Winaputra, 
2005:3). Oleh karena itu, kegiatan pembelajaran merupakan kegiatan yang bertujuan dan bertahap. Seiring pesatnya perkembangan informasi dan teknologi, berdampak memicu perkembangan media pembelajaran, baik itu software maupun hardware, sehingga peran guru sebagai sumber belajar pun perlahan-lahan tetapi pasti akan berubah menjadi guru sebagai fasilitator. Oleh karena itu, ketika pola pembelajaran bermedia mulai mendominasi pembelajaran di kelas maupun di luar kelas, maka peran guru sebagai fasilitator sangat diharapkan agar dapat mendesain model pembelajaran yang sungguh-sungguh dapat mengantar peserta didik untuk dapat lebih mandiri dalam memahami materi ajar yang disajikan dalam kelas maupun di luar kelas. Sebagaimana dikemukakan oleh Joyce dkk (2009) bahwa model pembelajaran merupakan model belajar dengan model tersebut guru dapat membantu siswa untuk mendapatkan atau memperoleh informasi, ide, keterampilan, cara berpikir, dan mengekspresikan ide diri sendiri. Selain itu, mereka juga mengajarkan bagaimana peserta didik belajar.

Bruce and Joyce Marsha Weil (1986) dalam bukunya models of teaching mengelompokkan model belajar menjadi empat rumpun yaitu rumpun model informasi, rumpun model personal, rumpun model interaksi sosial, dan rumpun model behavioral (perilaku). Model pembelajaran latihan inquiry sendiri tergolong dalam kelompok model pengolahan informasi. Model pemrosesan informasi dipelopori oleh Gagne tahun 1985 dan teori belajar yang mendasari penerapan model pemrosesan informasi ini adalah teori belajar kognitif dari Piaget. Diprosesnya informasi oleh peserta didik secara mandiri dapat berpengaruh positif pada peningkatan pengetahuan dan keterampilannya. Pembelajaran dikaitkan dengan proses penerimaan informasi yang diolah dalam bentuk hasil belajar sebagai output. Interaksi kondisi internal bergabung dengan kondisikondisi eksternal. Perolehan dari pemrosesan informasi ini terwujud dalam kecakapan: (1) verbal, (2) intelektual, (3) strategi kognitif, (4) sikap, dan (5) motorik. Tahapan proses pembelajaran yang menerapkan pemrosesan informasi menurut Gagne meliputi: (1) motivasi, (2) pemahaman, (3) pemerolehan, (4) penahanan, (5) ingatan kembali, (6) generalisasi, (7) perlakukan, dan (8) umpan balik. Sementara untuk merealisasikan tahapan tersebut dalam kelas adalah dengan cara: (1) melakukan tindakan yang mampu menarik perhatian peserta didik, (2) memberikan informasi terkait tujuan dan topik yang dibahas dalam pembelajaran, (3) Menggerakkan peserta didik memulai aktivitas belajar, (4) menyampaikan isi pembelajaran sesuai dengan topik yang telah direncanakan , (5) memberikan bimbingan aktivitas belajar, (6) memberikan penguatan, (7) memberikan umpan balik, (8) melaksanakan penilaian proses dan hasil kerja, (9) memberikan kesempatan pada peserta didik untuk diskusi sesuai pengalaman yang mereka dapatkan. Rumpun model informasi berorientasi kepada kecakapan siswa dalam memproses informasi dan cara-cara mereformasi menekankan pada aspek kecakapan siswa untuk memecahkan masalah, menekankan pada berpikir produktif. 
Sejarah Indonesia merupakan mata pelajaran yang proses pembelajarannya banyak dilakukan dengan membaca buku, menghafalkan konsep-konsep, dan fakta yang ada. Dalam konteks pembelajaran seperti ini, siswa cenderung pasif, sebagian besar informasi telah tersedia dan diinformasikan guru. Proses pembelajaran menjadi kurang bermakna dan tidak mengembangkan kemampuan siswa untuk mengkonstruksi sendiri konsep-konsep sejarah Indonesia. Bentuk keterlibatan dalam pembelajaran biasanya menjawab pertanyaan tingkat rendah atau mengerjakan lembar kerja yang kurang menantang. Kondisi ini tidak sesuai dengan tujuan pembelajaran sejarah Indonesia yaitu siswa dapat lebih mengenal kehidupan masyarakat dan lingkungannya, memiliki kemampuan dasar untuk berpikir logis dan kritis, rasa ingin tahu, kemampuan memecahkan masalah, dan keterampilan dalam kehidupan sosial. Berdasarkan refleksi awal, kondisi ini disebabkan oleh: (1) guru hanya menuntut siswa menghafal beberapa fakta, konsep, prosedur, dan prinsip; (2) pembelajaran berpusat pada guru (teacher centered); (3) sumber belajar pada buku teks; dan (4) siswa kurang terlibat aktif dalam pembelajaran.

Untuk melibatkan siswa secara aktif dalam pembelajaran diperlukan model pembelajaran sejarah Indonesia yang tepat, misalnya model: "ceramah, inkuiri, diskusi, dan belajar dengan modul" (Purwanto, 2007: 27). Dengan berbagai model yang ada, guru haruslah memilih yang tepat ditinjau dari berbagai sudut pertimbangan. Oleh sebab itu kegiatan-kegiatan dan strategi harus berkaitan langsung dengan ide pokok dari unit yang akan diajarkan. Jika mengharapkan siswa mengembangkan kebiasaan berpikir kritis, mencari sendiri informasi, dapat menyusun hipotesis dan mengujinya, maka yang tepat digunakan adalah model inkuiri (inquiry model). Dalam pembelajaran yang menggunakan model inkuiri, pengetahuan dan keterampilan yang diperoleh siswa bukan hasil mengingat seperangkat fakta-fakta tetapi hasil dari menemukan sendiri.

Pembelajaran sejarah dengan bertujuan melatih kemampuan siswa untuk berpikir historis merupakan upaya untuk menjadikan pembelajaran sejarah sebagai media pembentukan keterampilan akademis tingkat tinggi dan pembentukan sikap dan pola perilaku ilmiah. Mengingat pentingnya proses pembelajaran tersebut maka selayaknya pembelajaran sejarah untuk melatih kemampuan berpikir historis perlu didukung dengan model pembelajaran yang sesuai. Model pembelajaran akan ikut menentukan keberhasilan tujuan pembelajaran mengingat melalui model pembelajaran inilah guru mampu merancang aktivitas siswa dan menentukan capaian-capaian yang diinginkan dengan menggunakan aktivitas terencana dalam proses belajar.

\section{PENGARUH MODEL PEMBELAJARAN INQUIRY LEARNING (LATIHAN PENELITIAN) UNTUK MELATIH SISWA BERPIKIR HISTORIS}

Menurut John Dewey, filsuf Amerika dan pendidik progresif, inquiry berawal dalam keadaan ketidakpastian atau ketidakseimbangan dan menyebabkan munculnya 
kebutuhan untuk mengatasi ketidakpastian dan mengembalikan keseimbangan (Dewey 1910) dalam (Lee, 2011). Kuslan Stone dalam Dahar (1991) mendefinisikan model inkuiri sebagai pengajaran di mana guru dan anak mempelajari peristiwa-peristiwa dan gejala-gejala ilmiah dengan pendekatan dan jiwa para ilmuwan. Sedangkan menurut Hamalik (1991) Pengajaran berdasarkan inkuiri adalah suatu strategi yang berpusat pada siswa di mana kelompok-kelompok siswa dihadapkan pada suatu persoalan atau mencari jawaban terhadap pertanyaan-pertanyaan di dalam suatu prosedur dan struktur kelompok yang digariskan secara jelas. Kourilsky (2009:1) menyatakan bahwa Model pembelajaran berdasarkan inkuiri merupakan suatu strategi yang berpusat pada siswa dimana kelompok siswa inkuiri ke dalam suatu isu atau mencari jawaban-jawaban terhadap isi pertanyaan melalui suatu prosedur yang digariskan secara jelas dan struktural kelompok.

Model latihan inkuiri telah kembangkan oleh Richard Suchman (1926) untuk mengajarkan tentang proses dalam meneliti dan menjelaskan fenomena asing. Model ini melibatkan siswa dalam versi versi kecil tentang jenis-jenis prosedur yang digunakan oleh para ahli untuk mengolah pengetahuan dan menghasilkan prinsip-prinsip. Didasarkan pada konsepsi metode ilmiah, model ini mencoba mengajarkan beberapa keterampilan dan bahasa penelitian ilmiah (Joyce dkk, 2011). Bruce dan Weil (1980) menyebutkan bahwa latihan inquiry dapat menambah pengetahuan sains, menghasilkan kemampuan berfikir kreatif, keterampilan memperoleh dan menganalisis suatu data. Ivany dan Collins (1969) dalam Bruce \& Weil (1980), model ini memperoleh hasil yang lebih baik saat konflik semakin menguat, pemunculan teka-teki dan pengalian atau pedalaman topik. Voss (1982) dalam Bruce \& Weil (1980) menyatakan bahwa inquiry dapat digunakan untuk pembelajar sekolah dasar dan menengah, dapat menarik perhatian pembelajar yang tuli (keterbatasan fisik).

Joyce, Weil, dan Calhoun (2009, hlm 201-202) menyebutkan bahwa model ini membawa siswa secara langsung ke dalam proses ilmiah melalui latihan-latihan yang dapat memadatkan proses ilmiah tersebut ke dalam periode yang singkat. Yang mana pengaruhnya dikemukakan Schlenker yakni latihan penelitian akan meningkatkan pemahaman ilmu pengetahuan, produktivitas dalam berpikir kreatif, keterampilan dalam memperoleh dan menganalisis informasi. Kesemuanya dibarengi pengulangan dan pengajaran dibarengi pengalaman laboratorium.

Pembelajaran adalah dampak dari berpikir. Retensi, pemahaman, dan penggunaan aktif pengetahuan bisa tercipta hanya dengan pengalaman pembelajaran di mana murid berpikir tentang, dan berpikir dengan, apa yang mereka pelajari (Perkins dalam Eggen \& Kauchak, 2012 : 110).

Berpikir historis mengharuskan kita mempertemukan dua pandangan yang saling bertentangan: pertama, cara berfikir yang kita gunakan selama ini adalah warisan 
yang tidak dapat disingkirkan, dan kedua jika kita tidak berusaha menyingkirkan warisan itu, mau tidak mau kita harus menggunakan "presentisme" yang membuat buntu kita pikiran itu, yang melihat masa lalu dengan kacamata masa sekarang (Wineburg 2006 : 18). Dengan demikian berpikir historis mengharuskan kita untuk dapat memahami konteks waktu. Begitu pula ketika kita mengajarkan siswa untuk menguasai keterampilan berpikir historis maka, konteks waktu menjadi hal penting yang harus diperhatikan siswa. Untuk melatih kemampuan tersebut diperlukan model pembelajaran yang memungkinkan siswa untuk mengeksplorasi berbagai fakta, membuat pertimbangan atas fakta-fakta tersebut dan mampu menjelaskan perumusan sistematis atas peristiwa sejarah yang mereka pelajari. Model pembelajaran yang dapat digunakan untuk melatih kemampuan tersebut antara lain model latihan penelitian.

Model latihan penelitian (inquiry training) bertujuan memperkenalkan siswa pada bidang keilmuan dengan cara melakukan penelitian. Domain level utama yang dilatih adalah kognitif level aplikasi, analisis, sintesis, dan evaluasi. Model latihan penelitian merupakan penyederhanaan dari langkah penelitian yang sebenarnya, tujuan utamanya adalah bagaimana siswa memahami masalah dan memahami bagaimana mendapatkan kebenaran ilmiah. Dalam pembelajaran sejarah sebenarnya model ini memungkinkan untuk digunakan pada kelas museum, akan tetapi jika tidak memungkinkan untuk menggunakan museum, model ini juga dapat digunakan untuk latihan penelusuran sumber dengan melakukan kajian pustaka. Model ini memungkinkan untuk merancang latihan penelitian sesuai bidang ilmu yang dipelajari.

Aplikasi dalam pembelajaran sejarah:

- Langkah 1; berhadapan dengan masalah

Guru menyajikan permasalahan, misalnya; mengapa Pemerintahan Orde Baru berakhir?

- Langkah 2; mengumpulkan data

Dalam tahap ini guru harus mengarahkan siswa untuk menemukan data dari tema yang dipilih, guru dapat mengarahkan siswa untuk mencari tahu mengapa terjadi krisis pada akhir masa orde baru?. Guru harus memastikan bahwa sumber data tersedia. Sumber data bisa dari koran, internet atau bahan pustaka.

- Langkah 3; mengolah, merumuskan penjelasan

Siswa dapat mengidentifikasi data yang diperoleh berdasarkan kurun waktu dan akibat yang ditimbulkan. Sesuai langkah 2, siswa diminta untuk mengidentifikasi dari beberapa faktor, faktor manakah yang mempunyai akibat fatal bagi stabilitas ekonomi dan politik pada akhir masa orde baru. Selanjutnya menguraikannya dalam sebuah deskripsi singkat. Tahap ini juga dapat 
disesuaikan dengan langkah kritik, interpretasi dan historiografi dalam penelitian sejarah.

- Langkah 4; menganalisis proses penelitian

Siswa dibimbing untuk memahami dan mengevaluasi kembali tahapan-tahapan yang dilalui, apakah sudah sesuai prosedur atau belum.

Model ini memungkinkan siswa untuk mencari/meneliti fakta sejarah secara mandiri dan mendapatkan pemahaman melalui kegiatan menemukan. Model ini memiliki susunan dan kerangka kerja yang cukup mudah, dan mendorong mekarnya iklim intelektual dalam kelas (Joyce, Weil dan Calhoun, 2011: 199).

Sutchman dalam model ini ingin siswa bersifat kooperatif dan ketat. Di mana siswa bersikap terbuka terhadap seluruh data yang relevan dengan latihan pelatihannya. Peran guru berada dalam tahap dua dan tiga, hanya untuk membantu bukan menjawab penelitiannya. Model ini memerlukan dukungan terkait material yang menopang permasalahan.

Penerapan model ini dapat dilakukan pada semua bidang, semua topik yang dapat dirumuskan menjadi suatu situasi yang membingungkan atau menjadi calon data latihan penelitian. Usia yang cocok dengan model ini adalah seluruh tingkatan umur yang mensyaratkan adanya penyesuaian. Di mana kembali lagi guru akan membuat setting yang memungkinkan untuk melakukan latihan penelitian ini. Dampak dari model ini adalah spirit kreativitas, kemandirian dan otonomi dalam pembelajaran, toleran pada ambiguitas, dan sifat pengetahuan yang tentatif.

Pembelajaran latihan inquiry berpengaruh pada:

1. Keterampilan proses (mengamati, mengumpulkan, dan mengorganisasikan data, mengidentifikasi dan mengontrol variabel, merumuskan dan menguji hipotesis dan menjelaskan; menarik kesimpulan).

2. Keaktifan siswa (belajar secara mandiri).

3. Keterampilan dalam mengungkapkan pendapat secara verbal.

4. Sifat toleransi terhadap keberagaman pendapat dan tekun.

5. Memiliki logika berpikir.

6. Kesadaran bahwa pengetahuan itu tentatif.

Proses belajar mengajar melalui inkuiri selalu melibatkan siswa dalam kegiatan bertukar pendapat melalui diskusi, seminar, dan sebagainya. Beberapa keuntungan dengan menggunakan inkuiri adalah sebagai berikut:

1. Membangun pemahaman konsep dan gagasan yang baik.

2. Membantu dalam menggunakan daya ingat dan transfer pada situasi-situasi proses belajar yang baru.

3. Mendorong siswa untuk bekerja dan berpikir atas inisiatif sendiri.

4. Membantu siswa untuk berpikir inisiatif dan merumuskan hipotesisnya sendiri. 
5. Memberi kepuasan yang bersifat intrinsik.

6. Mendorong terjadinya proses pembelajaran yang lebih menantang.

Sedangkan kelemahan pendekatan inkuiri menurut para ahli di antaranya: Menurut Sanjaya (2008:208) adalah: Sulit mengontrol kegiatan dan keberhasilan siswa; Pendekatan inkuiri sulit dalam merencanakan pembelajaran oleh karena terbentur dengan kebiasaan siswa dalam belajar; Kadang-kadang dalam mengimplementasikannya, memerlukan waktu yang panjang sehingga sering guru sulit menyesuaikannya dengan waktu yang telah ditentukan; Selama kriteria keberhasilan belajar ditentukan oleh kemampuan siswa menguasai materi pelajaran, maka akan sulit diimplementasikan oleh setiap guru. Menurut Lubis (2008:6) adalah: Dipersyaratkan keharusan adanya persiapan mental untuk cara belajar ini; Metode ini kurang berhasil untuk mengajar di kelas besar; Harapan yang ditimpahkan pada strategi ini mungkin mengecewakan guru dan siswa yang sudah terbiasa dengan perencanaan dan pengajaran secara tradisional; Metode ini dianggap terlalu mementingkan perolehan pengertian dan kurang diperhatikan diperolehnya sikap dan keterampilan; dan fasilitas untuk mencoba ide-ide mungkin belum lengkap.

Model latihan penelitian ini apabila dilakukan dengan baik, selain melatih kemampuan berpikir siswa juga dapat melatih sikap akademis siswa. Berdasarkan beberapa tinjauan dapat diketahui kesulitan utama dalam penggunaan model ini adalah keterbatasan sumber berupa buku teks sejarah yang tersedia di sekolahan. Berbagai alternatif dapat digunakan, misalnya dengan menggunakan sumber online di internet. Jika cara ini digunakan maka guru harus memberi pemahaman kepada siswa pentingnya kredibilitas dan validitas sumber. Siswa harus dilatih untuk melakukan proses kritik terhadap sumber internet yang mereka temukan.

\section{PENUTUP}

Model latihan penelitian dikembangkan oleh Richard Suchman yang mana tujuannya untuk menjelaskan fenomena asing atau mengajarkan siswa tentang proses meneliti. Model Latihan Penelitian menekankan peserta didik pada menguasai strategi penelitian dan semangat kreatif dalam penelitian. Ini sebabnya mengapa siswa harus berpartisipasi aktif dalam penelitian ilmiah atau pembahasan sebelumnya.

Ketika seorang guru mengajarkan siswa untuk menguasai keterampilan berpikir historis maka konteks waktu menjadi hal penting yang harus diperhatikan siswa agar dapat menguasai keterampilan berpikir historis. Untuk melatih kemampuan berpikir historis tersebut dapat menggunakan model latihan penelitian sebagai alternatif untuk mengembangkan cara belajar siswa dalam menemukan, memproses, dan menjadikan pengetahuan sebagai milik mereka. Dengan demikian pengetahuan yang mereka miliki 
bukan merupakan informasi baku yang disampaikan oleh guru, akan tetapi pengetahuan yang diolah sendiri oleh siswa.

\section{DAFTAR PUSTAKA}

Andayani. (2015). Problematika dan Aksioma : dalam Metodologi Pembelajaran Bahasa Indonesia. Yogyakarta : Deepublish.

Anwar, Muhammad. 2018. Menjadi Guru Professional. Jakarta : Prenadamedia Grup.

Erlina, S. (2019). Upaya Meningkatkan Aktivitas dan Hasil Belajar Sejarah Dengan Menggunakan Pendekatan Inkuiri Pada Siswa SMA Negeri 1 Metro. Jurnal Dewantara, 7(01), 122-135.

Heri, Susanto. Seputar Pembelajaran Sejarah; Isu, Gagasan Dan Strategi Pembelajaran. Aswaja Pressindo, 2014.

Ibrahim, Ibrahim. "PENERAPAN MODEL INKUIRI PADA MATA PELAJARAN SEJARAH INDONESIA PADA MATERI DAMPAK PENDUDUKAN JEPANG KE INDONESIA UNTUK MENINGKATKAN KEAKTIFAN SISWA DI SMK NEGERI 1 TARAKAN KALIMANTAN UTARA." Jurnal Borneo Humaniora 3.1 (2020): 01-08.

Joice, Bruce., Weil, Marsha dan Calhoun, Emily. (2009). Models of Teaching eight edition. USA : Pearson Education Inc.

JUNAEDI, Edi. MODEL LATIHAN INKUIRI (INQUIRY TRAINING MODEL); PEMBELAJARAN BERMAKNA YANG MELATIH KETRAMPILANKETRAMPILAN PENELITIAN. Quagga : Jurnal Pendidikan dan Biologi, 2015, 7.1.

Rusman. (2010). Model-model pembelajaran ; mengembangkan profesionalisme guru. Bandung : Mulia Mandiri Pers.

Susanto, Ahmad. Pengembangan pembelajaran IPS di SD. Kencana. 2014.

Susanto, H. (2015). Menghadirkan Kelas Konstruktivis dalam Melatih Kemampuan Berpikir Historis Melalui Model Latihan Penelitian.

SANDRA, Yofita. Analisis dan Refleksi Model-model Pembelajaran. 2019

Tayeb, T. (2017). Analisis dan manfaat model pembelajaran .AULADUNA : Jurnal Pendidikan Dasar Islam, 4(2), 48-55. 


$$
\text { . }
$$

